\title{
A COMPARISON OF CHANGES IN THE ACROSOMES OF DEEP-FROZEN RAM AND BULL SPERMATOZOA
}

\author{
P. F. WATSON AND I. G. A. MARTIN \\ Department of Veterinary Physiology, \\ University of Sydney, N.S.W., 2006, Australia
}

(Received 22nd Fune 1971, accepted 3rd September 1971)

The results from the insemination of frozen-thawed bull semen approach or equal those expected from natural mating, and contrast with the poor results obtained using frozen-thawed ram semen (Emmens \& Robinson, 1962). Healey (1969), describing the ultrastructural changes in spermatozoa resulting from freezing, noted differences between species in the degree of acrosomal deterioration.

This report summarizes the results of experiments on the cooling and deepfreezing of ram and bull spermatozoa. The degree of change in the acrosomes was estimated by means of light microscopy after the specimens had been stained with Giemsa, using the following scoring system: 0, normal acrosome; 1 and 2, stages of acrosomal damage; 3, acrosome entirely lost. A typical spermatozoon in each of the categories is shown in Text-fig. 1 .

Ejaculates from fifteen bulls were examined in one experiment and from twelve rams in a second experiment. Semen was diluted tenfold at $30^{\circ} \mathrm{C}$ and cooled to $5^{\circ} \mathrm{C}$ at a constant rate of $0.27^{\circ} \mathrm{C} / \mathrm{min}$. Further diluent, containing glycerol, was added at $5^{\circ} \mathrm{C}$ to bring the dilution to twentyfold, and the semen was frozen in ampoules containing 1 -ml portions after equilibration at $5^{\circ} \mathrm{C}$ for $1 \mathrm{hr}$. The freezing rate was approximately $3^{\circ} \mathrm{C} / \mathrm{min}$ to $-40^{\circ} \mathrm{C}$, followed by rapid cooling to $-196^{\circ} \mathrm{C}$. After storage for less than $1 \mathrm{hr}$, frozen samples were thawed by immersion of the ampoules in a water bath at $37^{\circ} \mathrm{C}$.

The final composition of the diluent was $205 \mathrm{~mm}$-glucose, $17 \mathrm{~mm}$-fructose, $49 \mathrm{~mm}-\mathrm{NaCl}, 5 \mathrm{~mm}-\mathrm{KCl}, 10 \mathrm{~mm}-\mathrm{Na}_{2} \mathrm{HPO}_{4}, 10 \mathrm{~mm}-\mathrm{NaH}_{2} \mathrm{PO}_{4} 6 \%$ egg yolk, v/v, and $7.5 \%$ glycerol, $\mathrm{v} / \mathrm{v}$. Before the addition of glycerol to the second-stage diluent, both diluents were centrifuged for $10 \mathrm{~min}$ at $1000 \mathrm{~g}$ to remove the larger globules of egg yolk.

Smears were made from samples of diluted semen at $30^{\circ} \mathrm{C}$, at $5^{\circ} \mathrm{C}$ after equilibration with glycerol, and after freezing and thawing. The smears were dried in warm air, fixed in neutral formol-saline (5\% formaldehyde) for 15 min, rinsed in tap-water, and stained in the following solution: $3.0 \mathrm{ml}$ Giemsa (Gurr R66), $2.0 \mathrm{ml}$ Sorensen's buffer ( $\mathrm{pH} \mathrm{7.0)}$ ) and $45.0 \mathrm{ml}$ distilled water.

All slides within each experiment were examined in random order and were so labelled that the observer did not know from which treatment the sample came. The acrosomes of the first twenty spermatozoa observed in a traverse of the smear were examined, and the mean score for these spermatozoa then became the unit of data for analysis of variance. 


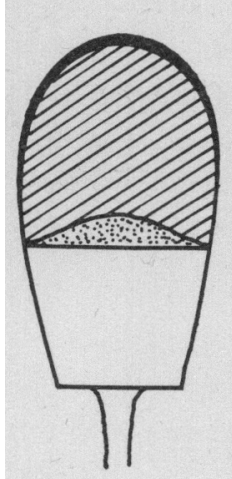

0

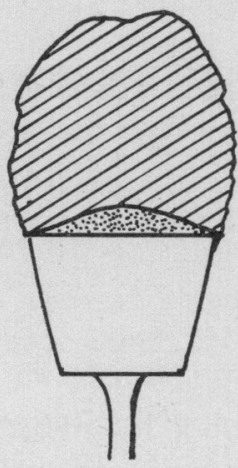

1

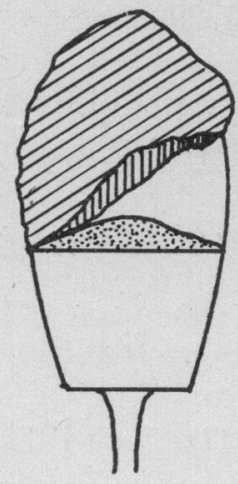

2

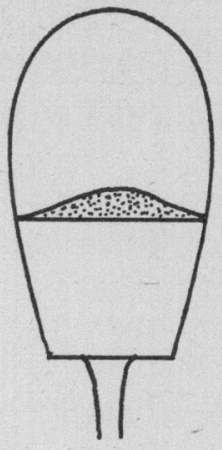

3

TExT-Fig. 1. Examples of spermatozoa from each of the score categories showing stages of acrosomal deterioration and loss: 0 , normal acrosome; 1, 'bubbling' and swelling of the acrosome; 2 , separation of acrosome from sperm head; 3 , acrosome entirely lost.

TABLE 1

COMPARISON OF THE GHANGE IN MEAN AGROSOMAL SGORE† FOR RAM AND BULL SPERMATOZOA SUBJEGTED TO FREEZING

\begin{tabular}{l|l|l}
\hline \multicolumn{1}{c|}{ Treatment } & Ram & Bull \\
\hline 1. At $30^{\circ} \mathrm{C}$, after dilution & 0.48 & 0.67 \\
2. At $5^{\circ} \mathrm{C}$, 1 hr after glycerol addition & 0.50 & 0.67 \\
3. After freezing and thawing & 1.45 & 1.03 \\
\hline
\end{tabular}

SUMMARY OF ANALYSES OF VARIANGE (NON-ORTHOGONAL)

\begin{tabular}{l|c|c}
\hline \multicolumn{1}{c|}{ Source of variation } & \multicolumn{2}{|c}{ Variance ratios } \\
\hline Between 1 and 2 & $<1$ & $<1$ \\
Between 1 and 3 & $80 \cdot 43^{* * *}$ & $21 \cdot 80^{* * *}$ \\
Error variance & $0 \cdot 14$ & $0 \cdot 09$ \\
& $(22$ degrees of freedom $)$ & $(28$ degrees of freedom $)$ \\
\hline
\end{tabular}

$\dagger$ See text. $\quad * * * P<0.001$.

\section{TABLE 2}

EFFEGT OF GHILLING AND FREEZING ON THE MEAN NUMBER OF SPERMATOZOA IN EACH AGROSOME GATEGORY* FOR THE RAM AND THE BULL

\begin{tabular}{|c|c|c|c|c|c|c|c|c|}
\hline \multirow{3}{*}{ Treatment } & \multicolumn{8}{|c|}{ Acrosome score category } \\
\hline & \multicolumn{4}{|c|}{$\operatorname{Ram}$} & \multicolumn{4}{|c|}{ Bull } \\
\hline & 0 & 1 & 2 & 3 & 0 & 1 & 2 & 3 \\
\hline \multirow{2}{*}{$\begin{array}{l}\text { At } 30^{\circ} \mathrm{C} \text {, after dilution } \\
\text { At } 5^{\circ} \mathrm{C}, 1 \mathrm{hr} \text { after glycerol } \\
\text { addition } \\
\text { After freezing and thawing }\end{array}$} & $12 \cdot 9$ & $5 \cdot 2$ & $1 \cdot 3$ & 0.6 & $10 \cdot 2$ & $7 \cdot 2$ & $1 \cdot 6$ & $1 \cdot 0$ \\
\hline & $\begin{array}{r}12 \cdot 1 \\
2 \cdot 3\end{array}$ & $\begin{array}{l}6 \cdot 0 \\
7 \cdot 3\end{array}$ & $\begin{array}{l}1.6 \\
9.7\end{array}$ & $\begin{array}{l}0.3 \\
0.8\end{array}$ & $\begin{array}{l}9 \cdot 7 \\
5 \cdot 7\end{array}$ & $\begin{array}{l}7 \cdot 8 \\
8 \cdot 3\end{array}$ & $\begin{array}{l}2 \cdot 0 \\
5 \cdot 5\end{array}$ & $\begin{array}{l}0.5 \\
0.4\end{array}$ \\
\hline
\end{tabular}

* See text. 
The change in the mean scores for the acrosomes of spermatozoa from the two species are shown in Table 1. A highly significant deterioration was found for both ram and bull spermatozoa after deep-freezing. The error variances are of comparable dimension but the variance ratios for the treatment contrasts in the ram are far greater than those for the bull. It appears that the acrosomes of ram spermatozoa were more severely damaged by freezing than those of the bull, which supports the evidence in the electron micrographs published by Healey (1969).

The mean numbers of spermatozoa falling into each score category for the ram and for the bull are shown in Table 2. Of the ram spermatozoa, 48.3\% showed damage of score type 2 after freezing compared with $27.7 \%$ of the bull spermatozoa. Only $11.3 \%$ of the ram spermatozoa showed no acrosomal abnormality after freezing, whereas $28.7 \%$ of the bull spermatozoa were considered normal. Thus, the mean acrosomal score was a composite of both the degree of deterioration of individual spermatozoa and the proportion of spermatozoa showing damage.

The difference between the two species in their scores of damage sustained after deep-freezing was not sufficiently great to propose such damage as the sole factor influencing fertility after artificial insemination. A major determinant of fertility is the establishment of a population of viable spermatozoa in the cervical canal (Mattner, Entwistle \& Martin, 1969; Lightfoot \& Salamon, 1970). Intracervical deposition of semen in the oestrous cow is a relatively easy and repeatable technique using small numbers of spermatozoa, but this is not so in the case of the ewe. If ram spermatozoa are somewhat more severely damaged by freezing than bull spermatozoa, the two factors operating simultaneously could well cause the substantial difference in fertility.

This method provides a rapid and simple means of assessing acrosomal damage. Many samples can be examined in a short time. It is hoped that it will prove a valuable laboratory guide to potential fertility of frozen ram spermatozoa.

\section{REFERENCES}

Emmens, G. W. \& Robinson, T.J. (1962) Artificial insemination in the sheep. In: The Semen of Animals and Artificial Insemination. Ed. J. P. Maule. Commonw. Agric. Bur., Bucks.

HEALEY, P. (1969) Effect of freezing on the ultrastructure of the spermatozoa of some domestic animals. 7. Reprod. Fert. 18, 21.

Lightroot, R. J. \& Salamon, S. (1970) Fertility of ram spermatozoon frozen by the pellet method. I. Transport and viability of spermatozoa within the genital tract of the ewe. F. Reprod. Fert. 22, 385.

Mattner, P. E., Entwistle, K. W. \& Martin, I. C. A. (1969) Passage, survival, and fertility of deepfrozen ram semen in the genital tract of the ewe. Aust. F. biol. Sci. 22, 181. 